Creative Commons User License: CC BY-NC-ND

Abstracted by: EBSCOhost, Electronic Journals Service (EJS),

Google Scholar, Journal Seek, Scientific Commons,

Food and Agricultural Organization (FAO), CABI and Scopus
Journal of Agricultural Extension

Vol. 23 (1) January, 2019

ISSN(e): 24086851; ISSN(Print); 1119944X

http://journal.aesonnigeria.org

http://www.ajol.info/index.php/iae

Email: editorinchief@aesonnigeria.org

\title{
Attitude of Graduate Youths Towards Agro-allied Skill Acquisition and Entrepreneurship Development Programme in Oyo State
}

https://dx.doi.org/10.4314/jae.v23i1.2

\section{Adelakun, Olubunmi Jokotola}

Institute of Agricultural Research and Training, Moor Plantation, Ibadan, Nigeria olubunmiadelakun@gmail.com; 08061613227

\section{Lawal, Bosede Olukemi}

Institute of Agricultural Research and Training, Moor Plantation, Ibadan, Nigeria bosedelawal@gmail.com; 08162005868

\section{Oyegbami, Ajoke}

Institute of Agricultural Research and Training, Moor Plantation, Ibadan, Nigeria titi oyegbami@yahoo.com; 08033657990

\section{Oyedokun, Margaret Olayemi}

Institute of Agricultural Research and Training, Moor Plantation, Ibadan, Nigeria oyedokunolayemi@hotmail.com; 08037267364

\section{Abstract}

The paper investigated the agro-allied aspect of the Skill and Entrepreneurship Development (SAED) programme of the National Youth Service Corps in Oyo State. Specifically, the study examined the personal characteristics of the corps members, determined the attitude of the corps members to agro-allied activities of the SAED and identified challenges facing corps members in executing the agro-allied activities. Pre-tested questionnaire was used to elicit information from $100 \%$ of the SAED participants which gave a total of 82 graduate youths. Data were analysed using descriptive and inferential statistics. The majority (67.1\%) of the youths were female. More than half (54.9\%) of the youths were in the age category of 24-26 with more than $62.7 \%$ having Bachelor of Science/Technology degree. Only $17.1 \%$ of the youths had a degree in agriculture. Majority (79.3\%) of the youths were into livestock production and $20.7 \%$ chose agricultural engineering. Financial independency and ability to manage resources (67.6\%), ability to innovate and inspire other youths $(12.0 \%)$ were the major motivations of youth. The majority $(64.0 \%)$ of the corps members are favourably disposed towards the programme. Challenges to entrepreneurship were poor supervision of the programme by National Youth Service Corps officials $(\bar{x}=1.89)$, lack of sufficient facilities for training ( $\bar{x}=1.85)$, inconsistence government policies ( $\bar{x}=1.84)$, incompetence of some of the facilitators $(\bar{x}=1.74)$ and lack of motivational support by government and other stakeholders $(\bar{x}=1.73)$. Sex $(x 2=21.07)$, educational qualification $(\mathrm{x} 2=7.47)$, and marital status $(\mathrm{X} 2=5.72)$ had significant association with attitude. Youth attitude and benefits derived from SAED programme were found to be significant $(r=0.38)$. For further involvement and positive attitude of graduate youths to agro-allied skill set of SAED, financial 
Creative Commons User License: CC BY-NC-ND

Abstracted by: EBSCOhost, Electronic Journals Service (EJS),

Google Scholar, Journal Seek, Scientific Commons,

Food and Agricultural Organization (FAO), CABI and Scopus
Journal of Agricultural Extension

Vol. 23 (1) January, 2019

ISSN(e): 24086851; ISSN(Print); 1119944X

http://journal.aesonnigeria.org

http://www.ajol.info/index.php/iae

Email: editorinchief@aesonnigeria.org

http://eoi.citefactor.org/10.11226/v23i1

assistance, supervision, monitoring and psychological motivation should be improved upon by stakeholders and government during and after the youths service year so as to encourage more graduate youths to take up agriculture and agribusiness as a profession and means of livelihood. Engaging graduate youth in agriculture and retaining them in the sector is a strategy that could both contribute to increasing agricultural productivity and address youth unemployment.

Keywords: Entrepreneurship Development, Graduates Youth, Attitude and Employment.

\section{Introduction}

Before the advent of crude oil, the nation's economic sectors (agricultural, industrial, health services and public service sector) were able to effectively generate employment and income for the country. The sectors also ensured food, nutritional security and livelihood enhancement (Omoroguiwa et al., 2014). However, during the period of oil boom, attention was shifted from the economic sectors and livelihood generating activities (Ojebiyi et al, 2015). There was total reliance on the oil while agriculture was neglected. The recent dwindling in oil price with adverse effects on the country especially on youths include economic recession, high rate of unemployment, poverty and vices. As a result of the adverse effects of overconcentration and dwindling of oil price, Nigeria government has been working relentlessly to achieve youth independence and improved economic status through several reforms and programme initiatives. Some of these initiatives include National Directorate of Employment (NDE) initiated 1986, Youth Enterprise with Innovation in Nigeria (YOUWIN) initiated 2011 and Skill Acquisition and Entrepreneurship Development (SAED) of the National Youth Service Corp (Ekong and Ekong, 2016). This is because 80\% of graduate youths find it hard to get employment every year despite the fact that the country is endowed with abundant human and natural resources (Undiyaundeye, 2015).

SAED programme was initiated by Nigerian federal government to tackle youth unemployment in order to secure the future prosperity of the country. The programme started in the year 2012 with the National Youth Service Corp (NYSC) at the orientation camps in the 36 states of Nigeria including Federal Capital Territory Abuja with motivation and sensitization of corps members on importance of skill acquisition and entrepreneurship development by resource personnel. The youths are trained on entrepreneurship skills for a few days at the various orientation camps. From the available skill sets, each youth graduate is requested to select his/her skill set of interest which will be learnt for few days while on the camp. After the orientation camp, graduate youths are expected to undergo post camp training on the skill set chosen by them. The time frame for the skill acquisition depend on the skill set chosen by individual graduate youth. For instance, for the Agro-allied skill set, the training runs through the whole service year and participants are trained by private establishments/resource personnel that registered/partnered with National Youth Service Corps. Skill acquisition is the privilege, opportunity and ability of an individual to be trained on one or more task, job, occupation, business or any income generating activity and become an expert in it. Skill acquisition and entrepreneurship development is designed to 
Creative Commons User License: CC BY-NC-ND

Abstracted by: EBSCOhost, Electronic Journals Service (EJS),

Google Scholar, Journal Seek, Scientific Commons,

Food and Agricultural Organization (FAO), CABI and Scopus
Journal of Agricultural Extension

Vol. 23 (1) January, 2019

ISSN(e): 24086851; ISSN(Print); 1119944X

http://journal.aesonnigeria.org

http://www.ajol.info/index.php/iae

Email: editorinchief@aesonnigeria.org

http://eoi.citefactor.org/10.11226/v23i1

improve economic and human development through its positive impact on wealth creation, unemployment reduction, poverty alleviation, creativity and innovation production which invariably increase the gross domestic product of the country and increase psychological rewards for humans. Entrepreneurship development which has been globally accepted as an instrument of economic growth and development (Oghojafor et al., 2011; Emmanuel, 2013), is also a process of enhancing or improving skills acquired by a person which invariably brings about economic and social advancement in terms of quality of life of individual.

The mandates of SAED are to collaborate with agencies and stakeholders on skill acquisition and entrepreneurship, to advocate and influence policies on youth empowerment, to mobilize over 200,000 corps members, to develop the spirit of selfreliance in the corps members towards job creation, to train the corps members, have at least 100,000 young entrepreneurs and then develop policies that will sustain the programmes. At the end of the SAED programme, graduate youths are expected to become entrepreneurs and employers of labour. According to Asogwa and $\operatorname{Dim}$ (2016), the programme is expected to bring about responsible creation and expansion of opportunities to a large extent for the other two economic activities, that is, employment and profession. Against this backdrop, it becomes imperative to assess the attitude of graduate youths towards the programme. This study assessed the attitude of graduate youths towards SAED in selected local government areas of Oyo State, Nigeria. Specifically, the study:

1. described the personal characteristics of graduate youths involved in SAED programme;

2. ascertained their motivational factors for participating in agro-allied skill;

3. ascertained the benefits derived from the SAED programme by the graduate youths;

4. assessed the attitude of graduate youths towards agro-allied skill; and

5. identified challenges experienced by the graduate youth on the programme;

\section{Research hypotheses}

$\mathrm{H}_{0} 1$ : There is no significant association between the personal characteristics of respondents and their attitude towards SAED programme.

$\mathrm{H}_{02}$ : There is no significant relationship between the benefits of SAED and attitude of graduate youths.

\section{Theoretical framework}

This study drew from Daniel Karz functionalist theory of attitude which proposed that attitudes are determined by the functions they serve for people. People hold given attitudes because these attitudes help them achieve their basic goals. It also states that psychologically, attitude meet four basic functions which are: instrumental (people especially youths develop favourable attitude towards initiatives or programme that improve their livelihood and social welfare benefits which will invariably maximise rewards and minimise undesirable consequences), knowledgeable (youths tend to seek for some degree of order, clarity and stability in their personal frame and complexity of life and via attitude as a stereotype, what youths seek for will be provided for),value expressive and ego defensive. 
Creative Commons User License: CC BY-NC-ND

Abstracted by: EBSCOhost, Electronic Journals Service (EJS),

Google Scholar, Journal Seek, Scientific Commons,

Food and Agricultural Organization (FAO), CABI and Scopus
Journal of Agricultural Extension

Vol. 23 (1) January, 2019

ISSN(e): 24086851; ISSN(Print); 1119944X

http://journal.aesonnigeria.org

http://www.ajol.info/index.php/iae

Email: editorinchief@aesonnigeria.org

http://eoi.citefactor.org/10.11226/v23i1

Katz's functionalist theory also explains reasons for change in attitude, it states that attitude changes when it no longer serves its function which will eventually leads to frustration. Attitude change is achieved not so much by changing youths' information or perception about some initiatives, but rather by changing their underlying motivational and personality needs. The psychological functions and reasons for change in attitude guided this research study to identify challenges and the graduate youths' characteristics to be assessed as the predictors of their derived benefits and attitudes towards SAED programme.

\section{Methodology}

The study was conducted in Oyo State, Nigeria. The State is located in south-western part and lies within latitude $8.41^{\circ} \mathrm{N}$ and longitude $3.42^{\circ} \mathrm{E}$, it covers an area of $27,249 \mathrm{~km}^{2}$. It is bounded in the South by Ogun State, in the North by Kwara State, west partly bounded by Ogun State and partly by Republic of Benin, East bounded by Osun State (NPC, 2006). The ecological Zone of this area ranges from rain forest and mangrove forest. Crops usually grown include maize, yam, cassava, cocoyam, melon, cowpea, cashew, and vegetable under mixed cropping practices. It consists of thirty-three local government areas (LGAs) twenty-eight of them are rural LGAs.

The study population covers all National Youth Service Corps members in Oyo State, Nigeria. Simple random sampling technique was used to select two (2) out of thirty-three (33) NYSC LGAs in the state, in the two selected Local Government Areas, $100 \%$ of the SAED participants were selected which gave eighty- two (82) graduate youths.

Pre-tested questionnaires were used to obtain information from the selected eighty- two (82) corps members) in the two LGAs.

Attitude was the dependent variable. Sixteen (16) positive and negative statements on graduate youths' attitudes towards agro-allied skill set of SAED were developed. Attitude was measured on a Likert type scale of strongly agree (5), agreed (4), undecided (3) strongly disagree (2), and disagree (1). Mean score $(41.78 \pm 8.55)$ was used to categorized their attitude into favourable $(\geq 41.78)$ and unfavourable $(<41.78)$.

Benefits derived from the programme by corps members were measured by requesting respondents to indicate the benefits derived which was measured as 'not at all' (1), to a less extent (2) to some extent (3) and to a large extent (4). Weighted mean score was obtained for each of the benefits which was used to rank the benefits in order of importance. The challenges of respondents on skill acquisition and entrepreneurship development, were measured by developing 10 statements with three points scale of 'not at a challenge' (1), 'minor challenge' (2) and 'major challenge' (3). Mean score was used to rank the challenges. Data collected were collated and analysed using descriptive and inferential statistics. Simple frequency counts, percentages and mean were used to summarize the data while Pearson's Product Moment Correlation analysis was used to test the relationship between benefits derived and attitude towards the programme. Chi square was used to test the association between personal characteristics of corps members and attitude. 
Creative Commons User License: CC BY-NC-ND

Abstracted by: EBSCOhost, Electronic Journals Service (EJS),

Google Scholar, Journal Seek, Scientific Commons,

Food and Agricultural Organization (FAO), CABI and Scopus

http://eoi.citefactor.org/10.11226/v23i1
Journal of Agricultural Extension

Vol. 23 (1) January, 2019

ISSN(e): 24086851; ISSN(Print); 1119944X

http://journal.aesonnigeria.org

http://www.ajol.info/index.php/iae

Email: editorinchief@aesonnigeria.org

\section{Results and Discussion}

\section{Personal and Socio-economic Characteristics of Graduate Youths}

Table 1 shows that more than half $(54.9 \%)$ of the corps members were within the age range of 24 to 26 years, while 25.6 percent were within the age of 21 and 23 years. The mean age was $23.7 \pm 5.01$ years. More than 12 percent were in the age range of $27-29$ years and only 2.4 percent were more than $30 y e a r s$ of age. This shows that the graduate youths were still in their productive age wherein their energies could be harnessed and utilised for productive ventures in agriculture. Majority (67.5\%) of the graduate youths were female while $32.3 \%$ were male. This contradicts the findings of Tijani and Ayinla (2015) that more males were involved in agricultural programmes because of the drudgery associated with the enterprise. With the scarcity of jobs and high rate of unemployment, most female graduate youths remain traditional resource confined to homes. Few of the them knock on office doors everyday with their curriculum vitae seeking jobs and these situations incapacitate them to transform what has been learnt in school into thriving enterprises. Also, 94\% were single while $6 \%$ were married. This shows that graduate youths desire discoveries which spark their interest, add value to their lives and make them independent, hence seek for initiatives or development programmes which can make them achieve their independent goals. About $81 \%$ of the graduate youths had university degrees such as B.Sc., B. Tech., B. Edu., LLB., while only $17.1 \%$ had Bachelor of Agriculture. This result supports the findings of Nwaogwugwu and Obele (2017), that less youths take up agriculture as profession because of poor social and wrong values attach to agriculture in the nation.

Table 1: Personal characteristics of the respondents

\begin{tabular}{lll}
\hline Variables & Percentage (\%) & Mean \pm SD \\
\hline Age & & \\
$18-20$ & 4.9 & \\
$21-23$ & 25.6 & $23.73 \pm 5.01$ \\
$24-26$ & 54.9 & \\
$27-29$ & 12.2 & \\
$\geq 30$ & 2.4 & \\
Sex & 32.5 & \\
Male & 67.5 & $1.06 \pm 0.24$ \\
Female & 93.9 & \\
Marital status & 6.1 & \\
Single & & \\
Married & 19.5 & \\
Educational qualification & 17.1 & \\
HND & & \\
B. Agric. & & \\
B. Sc., B. Tech., B. Edu., LLB., & 63.4 & \\
etc. & \\
Agro allied & & \\
Livestock rearing & 79.3 & \\
Agricultural engineering & 20.7 & \\
Crop production & 0.0 & \\
& &
\end{tabular}

Source: Field survey, 2016 
Creative Commons User License: CC BY-NC-ND

Abstracted by: EBSCOhost, Electronic Journals Service (EJS),

Google Scholar, Journal Seek, Scientific Commons,

Food and Agricultural Organization (FAO), CABI and Scopus
Journal of Agricultural Extension

Vol. 23 (1) January, 2019

ISSN(e): 24086851; ISSN(Print); 1119944X

http://journal.aesonnigeria.org

http://www.ajol.info/index.php/iae

Email: editorinchief@aesonnigeria.org

http://eoi.citefactor.org/10.11226/v23i1

\section{Motivation, Source of Fund and Willingness of Graduate Youths' to Participate in the Programme}

Table 2 shows the motivational factors for graduate youths' participation in SAED programme. The majority $(65.6 \%)$ of the youths indicated financial independency and ability to manage human and material resources as major factor that motivated them to choose the agro-allied skill set. Ability to innovate and be employers of labour were mentioned by $12 \%$ and $10.8 \%$ of youths, respectively. Other reasons mentioned were unemployment $(4.8 \%)$, ability to add value to life $(2.4 \%)$, economic recession $(1.2 \%)$ and professionalising area of study $(1.2 \%)$. Inability of the nation's economy to generate sufficient job opportunities is one of the reasons youths are now going into self-employment. Every year, thousands of graduates are turn out from various educational institutions into the congested labour market. This corroborate the findings of Salau (2014), who posit that unemployment, innovations and value addition were among the motivational factors for graduate youths' participation in skill acquisition and entrepreneurship development.

When respondents were further asked about their willingness to be an entrepreneur after the service year, majority $(82.9 \%)$ of the youths were willing to be an entrepreneur and contribute to the economy of the nation, while $48.8 \%$ prefer to source for start-up funds from their personal savings because getting loans from financial institution requires collateral which they do not possess. This support the findings of Aligba and Fusch (2017), that finance/fund serve as motivational factor for graduate youths' participation in skill acquisition and entrepreneurship development. Hence, there is need for improvement on motivational factors from government and other stakeholders, in order to increase the number of graduate youths' participation in agro-allied enterprises.

Table 2: Motivational factors, source of fund and willingness of graduate youths' involvement in skill acquisition and entrepreneurship development

\begin{tabular}{ll}
\hline Variables & Percentage (\%) \\
\hline $\begin{array}{l}\text { Motivational factors } \\
\text { to employer of labour }\end{array}$ & 10.8 \\
Ability to innovate and inspire & 12.0 \\
others & \\
Financial independent and & 67.6 \\
ability to manage human and & \\
material resources & \\
Adding values to life & 2.4 \\
Economic recession & 1.2 \\
Unemployment & 4.8 \\
Professionalising area of study & 1.2 \\
Source for fund & \\
Loans & 31.7 \\
Personal capital & 48.8 \\
Loans and personal capital & 17.1 \\
Relatives and friends & 2.4 \\
Willingness & \\
Willing & 82.9 \\
Not willing & 17.1 \\
\hline
\end{tabular}

Source: Field survey, 2016 
Creative Commons User License: CC BY-NC-ND

Abstracted by: EBSCOhost, Electronic Journals Service (EJS),

Google Scholar, Journal Seek, Scientific Commons,

Food and Agricultural Organization (FAO), CABI and Scopus

http://eoi.citefactor.org/10.11226/v23i1
Journal of Agricultural Extension

Vol. 23 (1) January, 2019

ISSN(e): 24086851; ISSN(Print); 1119944X

http://journal.aesonnigeria.org

http://www.ajol.info/index.php/iae

Email: editorinchief@aesonnigeria.org

\section{Benefits Derived from Participating in Agro-Allied Skill of SAED Programme.}

Benefits derived by graduate youths from the agro-allied programme are shown in Table 3. Respondents indicated that, their participation in the programme resulted in improved standard of living $(\bar{x}=2.38,1.04)$, increased self-esteem $(\bar{x}=1.94,0.91)$ and broader thinking process $(\bar{x}=1.94,0.88)$. This is an indication that graduate youths had cognisance of the derived benefits of the programme and that the programme enabled their capacity building. This is in line with the findings of Ihugba et al (2013) that improved standard of living through broader thinking process is part of the benefits associated with participation in skill acquisition and entrepreneurship development.

Table 3: Benefits derived by graduate youths from SAED programme

\begin{tabular}{lll}
\hline Benefits & Mean & $\begin{array}{l}\text { Standard } \\
\text { deviation }\end{array}$ \\
\hline Empowered for future & 1.85 & 0.82 \\
Increased self-esteem & 1.94 & 0.91 \\
Self-dependence & 1.87 & 0.97 \\
Improve skills & 1.76 & 0.85 \\
Broader thinking process & 1.94 & 0.88 \\
Improved standard of living & 2.38 & 1.04 \\
\hline
\end{tabular}

Source: Field survey, 2016

\section{Attitudes of Graduate Youths Towards the SAED Programme}

The data in Table 4 show that graduate youths strongly disagreed with the statement that SAED devalue corps members $(\bar{x}=4.3,0.9)$, is a waste of time $(\bar{x}=4.0,0.9)$ and that the programme prepares youth for the future $(\bar{x}=2.4,1.5)$. They strongly agreed that SAED can reduce attention shifted to white collar jobs $(\bar{x}=4.0,1.1)$, the programme is fulfilling its stated objectives $(\bar{x}=4.0,1.3)$ and also give room for innovation $(\bar{x}=3.8,1.6)$. These results show that though there is positive disposition of graduate youths towards SAED programme the programme is still not fulfilling its stated objectives.

The graduate youths had favourable attitude towards agro-allied skill set of SAED $(\bar{x}=\geq 41.78,8.55)$. This is an indication that, respondents have the cognisance of the importance of the programme which made them to have favourable attitude towards it. This corroborates with the findings of Thomas and Eforuoku (2016) that youths have favourable attitude towards skill acquisition and entrepreneuship development because of the innovations embedded in it, which make them to always explore new ideas that will enhance their livelihood activities and make them to be self-reliant instead of depending on the whitecollar jobs. 
Creative Commons User License: CC BY-NC-ND

Abstracted by: EBSCOhost, Electronic Journals Service (EJS),

Google Scholar, Journal Seek, Scientific Commons,

Food and Agricultural Organization (FAO), CABI and Scopus

http://eoi.citefactor.org/10.11226/v23i1
Journal of Agricultural Extension

Vol. 23 (1) January, 2019

ISSN(e): 24086851; ISSN(Print); 1119944X

http://journal.aesonnigeria.org

http://www.ajol.info/index.php/jae

Email: editorinchief@aesonnigeria.org

Table 4: Attitude of Graduate Youths Towards Agro-Allied Skill Set of SAED Programme

\begin{tabular}{|c|c|c|}
\hline Attitude & $\mathbf{M}$ & SD \\
\hline SAED devalues corps members & 4.3 & 0.9 \\
\hline $\begin{array}{l}\text { SAED is a good programme initiated by } \\
\text { government }\end{array}$ & 3.9 & 1.6 \\
\hline SAED gives room for innovations & 3.8 & 1.6 \\
\hline SAED is a waste of resources & 4.0 & 0.9 \\
\hline SAED is a way out of economic recession & 3.9 & 1.3 \\
\hline SAED prepares youth for the future & 2.4 & 1.5 \\
\hline SAED results are long term & 3.2 & 1.1 \\
\hline SAED is indeed a youth initiative & 3.3 & 1.4 \\
\hline SAED exposes hidden talents & 3.8 & 1.4 \\
\hline SAED duration is short term & 3.9 & 1.3 \\
\hline SAED skill sets are not taught in-depth & 3.4 & 1.4 \\
\hline SAED is fulfilling its stated objectives & 4.0 & 1.3 \\
\hline SAED programme is government propaganda & 4.1 & 0.9 \\
\hline SAED involves good orientation and planning & 3.6 & 1.4 \\
\hline SAED programme can reduce attention on white & 4.0 & 1.1 \\
\hline $\begin{array}{l}\text { collar job } \\
\text { Through monitoring and evaluation, SAED } \\
\text { programme can be sustained }\end{array}$ & 3.4 & 1.3 \\
\hline Attitude categorised $(41.78 \pm 8.55)$ & $<41.78$ & \\
\hline $\begin{array}{l}\text { Unfavourable } \\
\text { Favourable }\end{array}$ & $\geq 41.78$ & \\
\hline
\end{tabular}

Source: Field survey, 2016

Challenges Experienced by Graduate Youths in SAED Programme

Table 5 shows the challenges experienced by corps members in the programme, which were ranked according to their severity. Major challenges were poor supervision of the programme by NYSC officials ( $\bar{x}=1.89)$, and lack of sufficient facilities for training $(\bar{x}=1.85)$. This is an indication that challenges if not taken care of, will continue to hinder graduate youths from being an entrepreneur/self-dependent. This corroborates the findings of Thomas and Eforuoku (2016) that lack/inadequate training facilities inhibit youths from participating in agricultural related skills and entrepreneurship development. 
Creative Commons User License: CC BY-NC-ND

Abstracted by: EBSCOhost, Electronic Journals Service (EJS),

Google Scholar, Journal Seek, Scientific Commons,

Food and Agricultural Organization (FAO), CABI and Scopus
Journal of Agricultural Extension

Vol. 23 (1) January, 2019

ISSN(e): 24086851; ISSN(Print); 1119944X

http://journal.aesonnigeria.org

http://www.ajol.info/index.php/iae

Email: editorinchief@aesonnigeria.org

http://eoi.citefactor.org/10.11226/v23i1

Table 5: Challenges experienced by graduate youths in SAED programme

\begin{tabular}{llcc}
\hline Variables & Mean & S.D & Rank \\
\hline Poor supervision of SAED by NYSC officials & 1.89 & 0.88 & 1 \\
Lack of sufficient facilities & 1.85 & 0.90 & 2 \\
Inconsistence policies & 1.84 & 0.78 & 3 \\
Incompetence of the facilitators & 1.74 & 0.89 & 4 \\
Lack of motivation from stakeholders & 1.73 & 0.85 & 5 \\
Profit making nature of the facilitators & 1.62 & 0.81 & 6 \\
Harnessing of raw local materials & 1.61 & 0.77 & 7 \\
Inadequate training materials & 1.61 & 0.73 & 7 \\
Mobilisation of domestic savings for investment & 1.60 & 0.74 & 8
\end{tabular}

Source: Field survey, 2016

\section{Relationship Between Benefits of the Programme and Attitude of Graduate Youths Towards SAED}

Table 6 reveals a significant relationship between benefits derived from the programme and attitudes of corps members towards SAED programme $(r=0.388, p=000)$. This significant relationship implies that the more the benefits derived from the programme, the more favourable attitude graduate youths have towards SAED programme. Youths favourable attitude is a function of the benefits derived from the programme. This supports the findings of Uddin et al (2015) that benefits of entrepreneurship programme are significant factors that motivate youths to have favourable attitude towards entrepreneurship development programme. Hence, the need for the NYSC officials to ensure the graduate youths realise maximum benefits from the programme.

Table 6: Benefits of SAED programme and attitude of graduate youths

\begin{tabular}{ll}
\hline Variables & R-value \\
\hline Benefits & $0.388^{*}$ \\
\hline${ }^{*} P \leq 0.01$ &
\end{tabular}

Source: Field survey, 2016

\section{Association of Graduate Youths' Personal Characteristics and Attitude}

Table 7 shows that graduate youths' sex $\left(x^{2}=3.539, p<0.05\right)$, educational qualification $\left(x^{2}=7.476, p<0.05\right)$, and marital status $\left(x^{2}=5.720, p<0.05\right)$ had significant association with their attitude. This implies that attitude of the youths is largely dictated by their sex, educational qualification and marital status, this is because education make graduate youths to be in-line with social trend. Also attachment of responsibilities with marital status makes them to be industrious and have favourable attitude towards SAED. This is in line with findings of Verhaest and Omey (2012) who ascertained that educational qualification is a significant factor in graduate youths' favourable attitude towards skill acquisition programme, because it enhances competency in their area of disciplines. 
Creative Commons User License: CC BY-NC-ND

Abstracted by: EBSCOhost, Electronic Journals Service (EJS),

Google Scholar, Journal Seek, Scientific Commons,

Food and Agricultural Organization (FAO), CABI and Scopus

http://eoi.citefactor.org/10.11226/v23i1
Journal of Agricultural Extension

Vol. 23 (1) January, 2019

ISSN(e): 24086851; ISSN(Print); 1119944X

http://journal.aesonnigeria.org

http://www.ajol.info/index.php/iae

Email: editorinchief@aesonnigeria.org

Table 7: Association of graduate youths' personal characteristics and attitude

\begin{tabular}{ll}
\hline Variables & $\mathrm{X}^{2}$ \\
\hline Sex & $3.539^{*}$ \\
Education & $7.476^{*}$ \\
qualification & \\
Marital status & $5.720^{*}$ \\
\hline${ }^{*} \mathrm{P} \leq 0.05$ &
\end{tabular}

Source: Field survey, 2016

\section{Conclusion and Recommendations}

This study ascertained that graduate youths had favourable attitude towards agro-allied skill set of the skill acquisition and entrepreneurship development programme which is an indication of youths' cognisance of the importance of the programme. However, major challenges faced by graduate youths in the programme include poor supervision of the NYSC officials and lack of sufficient facilities for training.

There is need for introduction of use of farm machineries into the crop production aspect of agro-allied skill to encourage graduate youths to go into crop production. Adequate financial assistance, training facilities, regular supervision and monitoring should be provided by stakeholders for graduate youths during and after the service year. This will sustain their positive disposition towards the programme and also encourage more graduate youths to take up agriculture and agribusiness as a profession and means of livelihood.

\section{References}

Aligba, O. A. and Fusch G. E. (2017). Entrepreneurial Motivations and Characteristics of Niger Delta Youths: An Exploratory Study. Journal of Social Change. 9(1): 87-99

Asogwa, O. S and Dim, Ethel-Mary (2016). Entrepreneurship and Unemployment Reduction in Nigeria. International Journal of Business Management Review. 4 (8):27-43

Ekong, M. U. and Ekong, C. U. (2016). Skill Acquisition and Employment Reduction in Nigeria: A Case Study of National Directorate of Employment in Akwalbom State. International Journal of Economics and Management Sciences. 5(4): 1-10. DOA: $10.41724 / 2162-6359.1000352$

Emmanuel, C.L (2013). Entrepreneurship: A conceptual approach. Pumark Nigeria Limited. P.393

Ihugba, O. A., Odii A. and Njoku A. C. (2013). Challenges and Prospects of Entrepreneurship in Nigeria. Academic Journal of Interdisciplinary Studies. 2(5): 2536

Nwaogwugwu, O.N. and Obele, K.N. (2017). Factors Limiting Youth Participation in Agriculture-based Livelihoods in Eleme Local Government Area of the Niger Delta, Nigeria. Journal of Scientia Agriculture 17 (3): 105-111. 
Creative Commons User License: CC BY-NC-ND

Abstracted by: EBSCOhost, Electronic Journals Service (EJS),

Google Scholar, Journal Seek, Scientific Commons,

Food and Agricultural Organization (FAO), CABI and Scopus

http://eoi.citefactor.org/10.11226/v23i1

Journal of Agricultural Extension

Vol. 23 (1) January, 2019

ISSN(e): 24086851; ISSN(Print); 1119944X

http://journal.aesonnigeria.org

http://www.ajol.info/index.php/iae

Email: editorinchief@aesonnigeria.org

National Population Commission, (2006). Census Provisional Result. National Population Commission, Abuja. Nigeria.

Oghojafor, B. E. A., Okonji, P. S., Olayemi, O. O. O. and Okolie, J. U (2011). Fifty Years of

Entrepreneurship Development in Nigeria: Challenges and Prospects. $10^{\text {th }}$ International Entrepreneurship Forum, Tamkeen, Bahrain. Pg. 1-11

Ojebiyi, W.G., Ashimolowo, O. R., Odediran, O.F., Soetan, O.S., Aromiwura, O.A. and Adeoye, A.S (2015). Willingness to Venture into Agriculture-related Enterprises after Graduation among Final Year Agriculture Students of Federal University of Agriculture, Abeokuta. International Journal of Agricultural and Apicultural Research (IJAAR). 11 (1\&2): 103-104

Omorogiuwa, O., Jelena Z and Fatima A. (2014). The Role of Agriculture in the Economic Development of Nigeria. European Scientific Journal. 10(4): 133-147

Salau, O (2014). Attitude of Youths and Young Graduates Towards Entreprenuership Skill Acquisition in Abeokuta, Ogun State: Issues and Prospects. International Journal of Economics and Management Sciences. 3(3): 1-11

Thomas, K.A and Eforuoku F. (2016). Determinant of Participation in Youth-in-Agriculture Programme in Ondo State, Nigeria. Journal of Agricultural Extension. 20(2): 104117

Tijani, S.A and Ayinla, M.A (2015). Effect of the NYSC/MDGS/WAP agro-enterprise loan on Beneficiaries's well-being in South West Nigeria. Nigerian Journal of Rural Sociology 15 (2):55-60.

Undiyaundeye, F. A. (2015). Entrpreneurship Skill Acquisition and Benefits Amongst the Undergraduate Students in Nigeria. European Journal of Social Sciences Education and Research. 5(1): 357-362

Verhaest, D and Omey E. (2012). The Relationship Between Formal Education and Skill Acquisition in Young Workers' First Jobs. Working Papers of Faculty of Economics and Business Administration, Ghent University, Belgium. Retrieved 16 November, 2018, from URL https://ideas.repec.org 